\title{
MACHINERY FOR THE ADJUSTMENT OF DISPUTES UNDER NEW COLLECTIVE AGREEMENTS
}

\author{
David A. McCABE*
}

The establishment of industrial peace through collective bargaining requires more than the signing of an agreement on terms of employment. The making of a collective agreement does not necessarily settle all the questions that arise between employer and employee during the period for which the agreement is signed. Where the parties have the fullest confidence in each other and a highly developed will to agree, they may settle each question as it arises, through conference, as a matter of course, without any preordained procedure. Experience has shown, however, that it is usually necessary to lay down a procedure in advance for the handling of disputed questions, if resort to coercion by one side or the other, or both, is to be avoided.

It cannot be too strongly emphasized that no machinery of adjustment will work well if either of the parties is determined to get its own way even if it has to resort to economic coercion to do so. Indeed, parties with a commendable measure of the will to agree have at times been unable to restrain some of their constituents from attempting to force the acceptance of a particular position rather than follow the agreed-upon procedure for the settlement of disputes. But this is not to say that the type of adjustment machinery has not an important bearing upon the workings of the collective agreement system. One might say that, given the amount of patience and willingness to compromise on the part of the two sides, the degree to which disputes will be settled without interruption of peaceful relations will vary with the adequacy of the adjustment machinery, objectively considered.

The adequacy of any type of adjustment machinery must be judged in relation to the strain put upon it by the content of the agreement with respect to the terms of employment. The agreement may be comprehensive in scope, or it may leave a number of important questions uncovered. The language of the agreement may be clear and definite or it may be vague or ambiguous. Obviously, if the wage schedules and other clauses of the collective agreement were inclusive enough to cover all questions that will arise, and so clear as to exclude conflicting interpretations, there

- A.P., 1904, Harvard; Ph.D., 1909, Johns Hopkins; Professor of Economics in Princeton University. Chairman, Newark Regional Labor Board, 1933-1934. Author: The Standard Rate in American Trade Unions; National Collective Bargaining in the Pottery Industry; co-author, with G. E. Barnett, Medintion, Intestigation and Arbitration in Industrial Disputes; co-author, with R. A. Lester, Labor and Social Organezation. 
would be no inherent need for a machinery for handling disputes. But this is difficult, if not impossible, to attain, even if it were desirable to make a collective agreement of so rigid a pattern.

The diffculty is largely technological. It increases with the number of variations in operations, working conditions and rates of pay. The piecework system, for example, ordinarily generates more points of dispute than the system of payment by the hour. The difficulty of making a comprehensive wage schedule is greater, too, if the agreement is to cover a number of plants instead of but a single plant. And the dynamic character of the industrial process itself is an almost insuperable obstacle to settling the exact rates of pay under all conditions for a year, or two or three years, in advance.

Other issues not so technological in origin are likely to be left somewhat in suspension by agreement makers because of the difficulty of agreeing on definite rules to cover all cases. This is especially true of matters that touch the question of discrimination between workers, such as the distribution of work, the order of layoff, and discharge. Clauses on these subjects in older agreements have often given rise to controversy as to their application to particular cases. This holds with particular force for clauses relating to discharge. Indeed, the application of any rule infringing upon what management regards as its right to "reward merit" on the one hand or to take "disciplinary action" on the other is likely to give rise to differences of interpretation. This likelihood is greater when the rule is new. It is so difficult to get agreement on the phrasing of a rule of this kind that the language first embodied in the agreement is often so general as to leave inevitable questions concerning its meaning to be answered when the particular cases arise. I am not arguing for the laying down of rigid rules, in advance, on these matters. But I am pointing to the burden that a rule that is worded in general terms puts on the adjustment machinery.

On the other hand, the failure to include any rule at all in the, agreement on a matter of this kind-distribution of work, order of layoff, discharge or other disciplinary action-will not avert controversy over the subject during the life of the agreement. Ignoring an issue does not eliminate it. No way has yet been found to confine disputes to subjects concerned directly with the interpretation of the clauses of the agreement or the application of its wage schedules. And if a controversy arises over some subject not touched upon in the agreement, the parties will be compelled, in practice, to deal with it through the adjustment machinery, if the agreement itself is not to be endangered by resort to coercion.

The burden put upon the adjustment procedure through narrowness in the scope of the agreement content or through the use of phraseology of general character is likely to be greatest when the parties are new to dealing with each other. If the agreement system survives, new clauses are added or existing clauses amended, from time to time, to cover more closely the issues that give trouble in the operation of the agreement. In some industries, through the functioning of a continuing procedure for the handling of disputes, decisions in particular cases attain the force of 
precedents and become, in effect, a part of the agreement. The ground subject to dispute becomes more and more restricted. But in the early days of collective bargaining in a trade or industry, the agreement content usually leaves many questions to the adjustment machinery, with little more than a general mandate as a guide.

The new agreements made in the last year or two are not, on the whole, to be excepted from this statement. By "new" agreements I mean agreements made by newly organized unions. I I do not include the renewals of agreements between unions and employers who have been dealing with each other for years. Nor do I include agreements made by old established national unions for newly acquired members, with employers who had not previously dealt with a union, where the union has brought the "new" employers into an existing agreement system, or has extended to them a form of agreement that is the result of years of experience in agreement making in that particular trade or industry. On the other hand, there are many agreements recently made by newly organized local unions of older national unions to which the above statement does apply.

The circumstances under which most of the new agreements were made were not favorable to the drawing up of agreements inclusive in content and explicit in statement. In very many cases the chief point at issue was apparently "union recognition." Indeed, some of the agreements seem to be more in the nature of agreements to establish collective bargaining relations than agreements fixing the terms of employment. For example, in the important matter of wages, some of the agreements contained no wage schedules but left the adjustment of alleged "inequalities" or "inequities" within the existing wage structure for later negotiation, or to whatever "grievance" procedure was to be set up. To be sure, some of these agreements called for horizontal wage increases over existing rates. This fact did not, however, change the underlying wage-rate structure.

The omission of detailed wage schedules, and of such allied matters as production standards, may be assumed to have been a practical necessity in the making of an agreement for the first time with a large company operating several plants, when the paramount issue was whether there was to be any agreement. It was not technical difficulties alone, however, that limited the scope of so many of the new agreements. Another factor was the reluctance of the employers to make any agreement at all with a union.

This is no new phenomenon in the history of collective bargaining. But never before had so many employers made agreements with unions under pressure other than that exercised by the strike, or strike threat, of a great majority of the workers. Never before had there been so much intervention by government officials, state as

\footnotetext{
${ }^{1}$ The list of new agreements surveyed by the writer is far from exhaustive, but it is believed to be representative. The conclusions in this article concerning the new agreements are based on agreements covering a large majority of the workers newly brought under agreements; however, the statements of quantitative character do not necessarily bold true of the new agreements as measured by tale instead of by coverage. The writer is indebted to the Industrial Relations Section of Princeton University for access to the texts of many of the new agreements.
} 
well as national, to secure agreements for newly organized workers. And never before had an employer faced the prospect of a court order to compel him "to bargain collectively" with an organization that could command the votes of but a bare majority of the workers. Many of the employers who entered into agreements last year did so with the hope that they would not have to renew them at their expiration. In this frame of mind the employers were naturally reluctant to tie their hands on any more matters than absolutely necessary. And the union negotiators were often willing, in order to get an agreement that would recognize the union, to refrain from pressing issues that they knew would have to be faced sooner or later.

One unusual feature in many of the new agreements, especially in agreements made by large companies, is the prohibition of coercion of workers not members of the contracting union. Discrimination by the company against union members is also forbidden, but this is not new; clauses forbidding discrimination for union membership or union activity were common in the older agreements. But rarely, if at all, did an agreement forbid coercion of non-members by the union or its members. Even if the agreement did not call for the closed shop-and there were many such agreements-it was not usual to refer in an agreement between a union and the employer to the presence of non-members. The clauses in the new agreements forbidding coercion of non-members are of a piece with the formula "recognition of the union for members only." They call attention to the fact that the question of the workers' adherence to the union is still 'open. A certification of majority representation by a Labor Relations Board; national or state, may end the "for members only" recognition, but it would not end the struggle for the allegiance of the nonmembers.

It is true that the "no coercion of non-members" clauses are open acknowledgment of the presence of a troublesome issue. The point is, however, that they do not remove it. They pass it on, in effect, to the adjustment machinery. It is difficult to put a prohibition of coercion of workers into self-enforcing language. Interpretations will differ on what constitutes coercion-whether of unionists or of non-unionists. Presumably, disputes over the coercion of unionists can be referred ultimately to the proper Labor Relations Board. But alleged violations of the prohibition of coercion of non-unionists by unionists are likely to be met by immediate disciplinary action by the employer or his agent. This may be a fruitful source of disputes for which some means of final settlement must be found by the union and the employer parties to the agreement; they do not belong to the Labor Relations Boards under the law as it stands.

Union insistence upon protection against discriminatory treatment of union men in distribution of work and tenure of employment, in this openly recognized "part union and part non-union" situation in the plants, helps to account for the prominence given in the new agreements to rules concerning distribution of work, layoff and discharge. On these particular matters the new agreements seem to have more to say than the older ones. Such rules occupy an especially important place in many of the large-company agreements. The greater emphasis on rules of this sort in the 
newer agreements may be attributable in large measure to depression experience. But it is doubtless due in part to the fear of discrimination in shops in which unionism is still an acute issue.

Here again the statement of a rule serves more to call attention to the problem than to solve it. Many of the clauses governing layoff are so worded that determination of which factor-seniority, efficiency, number of dependents, etc.-is to be controlling must be decided for each particular case. And the application of the rules governing discharges is, by the very nature of the subject, a matter for particular determination. The new agreements are no worse in this respect than the older ones; indeed, many of them are much more lengthy in wording than most of the older ones. However, the fact that they are new and therefore not interlined with precedents makes the task of adjusting disputes arising under them more difficult.

Enough has been said to show that the nature of many of the new agreements is such as to make the liability to disputes under them greater, on the whole, than under agreements of longer standing. Yet the provision in the new agreements for the handling of disputes-at least in a large number of agreements, representing a coverage of a majority of the workers brought under agreements for the first time within the past two years-is less adequate than that in many of the older ones. Nor is this strange. A smoothly working adjustment machinery, like a comprehensive and lucid agreement, has usually, in the past, been developed through experience rather than fashioned whole at the outset of collective bargaining relations.

I do not mean to imply that the new agreements ignore the necessity of making provision for the handling of disputes. Only a relatively small number of them make no reference whatever to the handling of disputes or grievances during the period of the agreement. Others contain a procedure for discharge cases alone. However, most of the texts that I have seen contain some stipulation as to what shall be done in case of a dispute over the interpretation or application of the terms of the agreement, and many state that this procedure shall be followed with respect to any dispute or grievance arising during the agreement period, whether the dispute is over a matter covered by the agreement text or not. In a considerable number of agreements, too, and especially in agreements with large companies, the "grievance procedure" is set forth at length. But, in most cases, the procedure outlined in the agreement is not one that insures that all grievances and complaints will be either settled speedily by agreement or carried to a final decision by an impartial referee or board without undue delay.

The assurance of a final decision, in the event of failure to reach a settlement with the employer, by some person or body not controlled by the employer, is essential to a satisfactory system; of adjustment of disputes. It must be remembered that in nearly all "disputes" it is the worker who is the complainant. The initial decision is made by the employer or his agent. It is the employer who decides, in the first instance, what is to be paid, or who is to be laid off, or called back to work, or whether this or that man is to be discharged. Collective agreements put limits to the employer's freedom of action in these matters, but the initiative in interpreting 
these limitations still rests with the employing side. The worker must either accept the employer's decision or appeal. If he appeals, a "grievance" or a "dispute" arises. When the employer is dissatisfied with what a worker does, or fails to do, he does not have to complain to the union; he-can discharge or otherwise discipline him and leave it to the worker to complain if he (the worker) holds that he has been dealt with unjustly. Thus the procedure for handling disputes is generally in practice a procedure for handling complaints from the workers. This is why it is so often called a procedure for the adjustment of "grievances"; a "grievance" in industrial relations parlance means a grievance of a worker or group of workers, never of an employer.

Inasmuch as a dispute is in effect an appeal by the worker for the overriding of a decision made by the employer or his agent, the worker loses if the procedure fails to procure action. Inaction or stalemate leaves the worker where he was before he protested or appealed. To be satisfactory to the workers the procedure must insure that, if a settlement is not reached by agreement, a decision will have to be given. Obviously, too, the procedure must provide that the decision shall be made by an outside body or person. Collective bargaining for terms of employment logically requires this. Unless an interpretation or application of the agreement can be appealed beyond the employer who is an interested party to the dispute, the terms agreed upon may be whittled away by $e x$ parte interpretation.

To be satisfactory to the workers, the procedure must also assure that grievances shall be brought to settlement or decision within a reasonable time. Delay is not necessarily fatal if there is assurance that it means merely postponement of a definite settlement or decision and not a stalemate. To be sure, delay may be irritating if it involves the continuance, meanwhile, of a situation that the workers contend violates the agreement and that cannot well be compensated for by making the decision retroactive, such as a condition adversely affecting the comfort or health' of the workers. But the margin of difference in a pay dispute, or a wage loss through a layoff or discharge that is later overruled, can be made up to the worker in the final settlement or decision and this is the practice under a number of the older agreements. However, the knowledge that the settlement or decision, if one is reached, will be retroactive is not very reassuring to workers during the period of delay if there is no certainty that there will be either a settlement or a decision. It is in this last respect that the new agreements are weak.

In many of the new agreements the provision for the handling of disputes goes little further than the recognition of the right of the union to take up the workers' case through its shop committee with the foreman and then, if no settlement is reached, to carry the case to the foreman's superior. 'This is no more than the traditional union practice in handling disputes in unionized shops. It does not, in and of itself, insure a settlement. It does, however, establish the union committee's position in the shop as against any tendency on the part of the foreman to compel either the individual worker or the shop committee to accept his decision as final. 
In agreements between the new organizations and large companies, especially in the mass-production industries, it is usual to outline the grievance procedure step by step, from the worker and the foreman to the national union officials and the executive officer or officers of the company, for those workers who are members of the union. If the worker fails to get satisfaction from the foreman, the matter is to be taken up with the foreman by the member of the union shop committee who acts for that department or district; if no settlement is reached, the union committee is to take the case to the plant manager; from there it goes directly, or perhaps through an intermediate company official, to the national union officers, and the chief executive of the company or some representative designated by the executive.

This charting of "grievance procedure" up through the hierarchy of management is reminiscent of the course of appeals laid down in the employee representation plans of large companies. It has long been the common practice of unions, also, to go to the "top" before resorting to direct action or to reference to an outside body, but it has not been usual in the older agreements to prescribe a definite hierarchial sequence. It is to be noted that the new agreements generally do not fix time limits between one step and the next, except in discharge appeals. Nor do they stipulate that settlements, when made, shall be retroactive to the date of the original protest or appeal, except, again, in discharge cases; a number of agreements specify that workers whose discharges are not sustained shall be reimbursed for the wage loss suffered.

Another common characteristic of the new agreement procedure, especially in the case of large companies, is a requirement that shop committee members shall be employees of the plant in which they serve. This is also, of course, the usual union practice. There is little danger of trouble in stating it in the agreement, unless the provision is used by superintendents or plant managers to keep "outside" union officers out of the picture while delaying the settlement of disputes with the shop committee. In the absence of any time limit on the handling of disputes within the plant, the workers may become impatient at what they regard as "stalling" by lesser officials. Under the older agreement systems, employers have frequently welcomed, or even asked, the participation of "outside" union officers at an early stage of the proceedings. Full-time union officers, who are not so closely associated with the workers who have the grievance as are the members of the shop committee, will often reach a settlement with the employer more quickly than the "insiders."

The provision for a two-sided consideration of a dispute by representatives who have wider jurisdiction than the shop committee and the plant manager, respectively, is an advance over a procedure that stops with the plant in which the dispute arises. The national officers of the union and the executives of a company operating several plants may be assumed to be farther removed from the heat of battle than the shop committee and the plant manager. Nevertheless, the company is still a party in interest, even if it is represented by its president. Therefore, the danger of deadlock still remains. The procedure thus far gives the employees no guarantee that they 
will not have to choose between accepting the employer's decision and resorting to a strike.

At this point it must be noted that the great majority of the new agreements are with single employers, not with an employers' association or a less formally organized group of employers. The adjustment procedure in these agreements is therefore limited to a type that involves only one employer. Some of the newly organized workers have been brought under a system of adjustment that covers a group of employers in the particular industry, but the workers so covered are but a small minority of the total covered by new agreements. Such systems are not easily introduced in industries hitherto unorganized, or very little organized, on the workers' side.

In the single-employer type of agreement the procedure for the settlement of disputes by two-sided action is exhausted when a deadlock is reached between the union and the highest official representing the company. If the dispute is to be referred elsewhere, it must be to a neutral referee or a board for arbitration. There is no two-sided body to which the dispute can be passed on, under the agreement. Reference of the case to an even-numbered committee, representing the union (or a group of unions) and an association of employers in that industry, is not available under an agreement confined to a single employer.

Space does not permit an appraisal here of the joint board, or joint committee, system of handling disputes that cannot be settled by the union and the employer directly in interest. It should be said, however, that settlements by such a board, or committee, of adjustment, while by no means received without grumbling, have generally proved more acceptable to the employers and the workers than decision by "outside" arbitrators. The system is, to be sure, subject to delay and deadlocks. The disadvantage of delay can be largely removed by making the decisions retroactive in cases involving pay or compensation. The liability to deadlock is usually met by a provision for reference to arbitration-commonly by adding a neutral member to the board-if the two sides are unable to reach a settlement within a given time. In any event the system presents a further opportunity for settlement by agreement between representatives of the two sides party to the agreement, representatives who, while not immediately interested in the particular dispute, do represent the respective points of view of the employers and employees in the industry.

With the joint board method of settlement unavailable under most of the new agreements, the only further procedure for amicable settlement is arbitration. And a very large proportion of the new agreements do carry arbitration provisions. In most cases, too, the arbitration is mandatory if requested by either side; the clause reads "shall" be referred, not "may" be referred, to arbitration. This is true of most, but not all, of the agreements with large companies; nearly all of them cap the procedure for two-way consideration up through the hierarchy of management with a provision that if the national union officers and the company executives cannot agree on a settlement, the dispute "shall" be referred to arbitration.

This is an advance over the procedure laid down in most employee representation 
plans. Many of these plans made no provision at all for appeal to arbitration from the decision of the head executive. And where there was a provision for arbitration, it often followed the "may" formula, which meant that the employer might decline to submit any particular case to arbitration. Yet the arbitration clauses in most of the new agreements-and again this applies to the agreements with large companies -fail to provide against a deadlock in selecting a referee or making up a board of arbitration. Most of the agreements provide merely that unsettled disputes shall be referred to a neutral referee, or a board of arbitration, to be designated "by mutual agreement" of the parties if and when the need for arbitration arises. There is, in most of the agreements, no time limit within which the arbitration machinery must begin to function, or any statement of what is to be done in case the union and the employer fail to reach "mutual agreement" upon who is to do the arbitrating.

Experience under similar arbitration provisions has shown that it is usually difficult and at times impossible for the parties in interest to agree on arbitrators after they have deadlocked on the merits of the issue involved. Ironically enough, some of the relatively small number of new agreements that fix a limit on the time that may elapse between the request for arbitration and the submission of the case to the arbitrators, fail to provide a sure-fire method of selecting them.

The attempt has often been made to avoid the liability of disagreement in the selection of a referee or a neutral member of an arbitration board by the device of having each party select an equal number of members of a board of arbitration and leaving to them the selection of the neutral member. This type of arbitration pro vision is also followed in some of the new agreements. But experience shows that this, too, is far from a sure-fire provision. The members selected by the respective parties may fail to agree upon a neutral colleague, at least within a time that the workers regard as reasonable. Even joint boards that have handled disputes for years have had difficulty in choosing neutral members to sit with them to resolve deadlocks. Under a number of agreements that provide for permanent joint boards it has been found necessary to stipulate that in the event of failure of the regular members of the board to agree on a neutral member within a stated time, he shall be designated by a specified person-such as the judge of a particular court, the governor of the state, or the president of a particular university-or a specified public body. Some of the new agreements contain such a provision, to apply in case the parties themselves, or members of an arbitration board selected by them, fail to complete the board within a stated time, but these agreements are relatively few.

Nor is there much resort in the new agreements to the practice of naming a referee in advance. This device has been used with noteworthy success under a number of the older agreements. It is generally called the "impartial chairman" system. In nearly all cases it is an outgrowth of a joint board or committee system, and, as the name implies, the arbitrator is still nominally chairman of a board. However, the system tends to become one of one-man arbitration of all the difficult cases. The "impartial chairman" device is confined almost entirely to agreements between unions and associations of employers, although it can be, and has been, used in an agreement 
between a single large company and a union. It is not employed in any of the new single-company agreements that I have seen.

Thus, it seems clear that the procedure set forth in the new agreements falls short, on the whole, of the best that experience has devised for reducing delay and preventing ultimate deadlock. This does not necessarily mean that it cannot be expected to produce satisfactory results. Whether or not the machinery will be so utilized as to avoid deadlocks, and even unreasonable delays, depends upon the people who have to work it. The fact remains, nevertheless, that it leaves the way open to delays and to ultimate deadlocks. And there is no reason apparent for expecting these types of adjustment machinery to be operated more successfully under the new agreements than they have been under the older ones.

On the contrary, there is one circumstance that enhances the liability to friction and delay in many plants. That is the recognition of the union for its members alone. It is in the handling of individual grievances that the distinction between members and non-members is made most apparent; the general terms of employment are presumably the same for members and non-members alike. There is danger that some foremen and superintendents, or even plant managers, may attempt to avoid making any concessions to the union members and to delay the progress of their cases to higher authority, in order to keep to a minimum what the union members get "through the union." And whether or not the foremen and superintendents-with whom the great majority of the questions that arise ought to be settled-are deliberately "stalling," the union members are likely to charge that they are, if the members believe them to be hostile to the union.

Obviously, a procedure for the adjustment of disputes that gives the workers reasonable grounds for dissatisfaction with it is not a successful one. I refer to dissatisfaction because of delays or failure to get the ultimate action that the agreement calls for, not to dissatisfaction with the terms of settlements or arbitral awards; dissatisfaction on the second ground is not properly chargeable to the procedure. A truly successful system of adjusting grievances would keep the labor relations within the plant harmonious. But to be considered even moderately successful it should prevent, or at least bring to quick termination, concerted quittings by aggrieved workers, whether these be "walk-outs" or "stay-in" strikes.

There is no doubt that failure to secure adjustment of grievances within what the workers regard as a reasonable time is an important source of strikes. In most grievance cases but a few men are directly involved. However, if these men quit, the number engaged in the stoppage is likely to grow rapidly unless the case is speedily settled. Some workers may quit in "sympathy"; others may quit because their work does not come through. Thus a dispute over a matter in which but a few men are immediately concerned may close a plant. This resort to direct action is not so likely to occur unless there has been an accumulation of. unredressed grievances. The liability to strikes is greater among newly organized workers than among workers long accustomed to the ways of grievance adjustment. Newly organized workers are, on the whole, impatient and inclined to strike if they do not 
get immediate results, especially if they have recently won union recognition, and perhaps other concessions, by striking.

Be it noted that I am discussing here the failure of adjustment machinery to prevent strikes because of the failure of the machinery itself to guard against delays and deadlocks. I am not discussing deliberate refusals on the part of workers to give the adjustment procedure a fair chance. No machinery of adjustment is proof against the determination of a group of workers to obtain their demands by direct action regardless of whether their demands contravene the agreement terms. Nor is it proof against the tactics of a faction that does not wish to secure peaceful adjustment of grievances so much as to discredit the whole process of amicable settlement in order to further the spread of the doctrine of the inevitability of class conflict under the "capitalistic system."

It is almost a universal corollary of the inclusion of an adjustment procedure in a collective agreement that there shall be no strike or lockout until the procedure has been exhausted. This is expressly stated in most agreements, new or old. In some of the new agreements with large companies there is the added stipulation that there shall be no strike or stoppage of any kind without the approval of the officers of the national union. Thus, under nearly all collective agreements any strike or concerted stoppage of work before the adjustment procedure has been complied with is a violation of the agreement.

Many agreements go further than this and forbid any strike or stoppage at all during the life of the agreement. These include some agreements in which the machinery leaves the way open to final deadlock. It would seem that a provision of this kind logically calls for an automatic provision for the final resolution of deadlocks by arbitration. Yet agreements are made with this gap in the system. I think this inconsistency is the result of careless drafting rather than of a deliberate attempt to compel the workers to choose between suffering quietly under "stalling" tactics and violating the agreement.

When, in the past, workers have gone on strike without having gone through all the steps laid down in the agreement, they have usually excused their own violation of the agreement by charging that the employer had violated the agreement first. The violation charged to the employer may have been an affirmative action, such as reducing an existing wage rate or increasing the speed or burden of work, without "mutual agreement"; in these cases the men have quit to compel immediate cessation of the employer's "violation." Or the violation complained of may have been "stalling" on the employer's side in the handling of grievances. Unless there is a specified limit on the time allowed for each step of the procedure, this charge is hard to prove-or to disprove. Under most of the new agreements, as has been pointed out, there are no such limits, except in discharge cases. And in the important matter of the selection of a neutral referee or the neutral members of a board of arbitration there is no assurance that a selection will ever be made. This is true of discharge appeals as well as of grievances in general.

The legal aspects of the enforceability of collective bargaining agreements is 
beyond the scope of this paper. It may be well to point out, however, that that part of enforceability that relates to strikes "in violation of the agreement" is closely connected with the question of what constitutes compliance with the adjustment procedure laid down in the agreement. Where no time limit is specified, how long may the company's agent delay action on a complaint before the union may demand action by a superior? Where no alternative method of selecting a neutral arbitrator is specified, in the event of failure of the parties, or of arbitrators selected by them, to agree, how long must the workers wait before they can be judged to have exhausted the adjustment procedure? Are workers to be punished for violations if the employer has already violated the agreement? Is deliberate "stalling" on the part of the company's agent to be considered a violation of the agreement? If so, what may be imputed as "deliberate stalling"? It seems likely that if the enforcement of compliance with agreement procedure for the adjustment of disputes becomes a matter of legal process generally, the matter of delay and the contingencies of deadlock will have to be much more adequately covered in the agreements than they are in most agreements today.

Another point to keep in mind is that there is a difference between a violation by a group of union members-workers in a particular plant or department of a . plant-and a violation by the union itself. If the union that makes the agreement does not itself order the strike-and especially if it orders the striking members to return to their jobs-it will hold that the violation is by a group of individuals and not by the union. If there is a provision in the agreement that there shall be no stoppage without the approval of the national union officers, this will merely emphasize the unauthorized character of the strike from the national union's standpoint.

In the past what the employers who have engaged in collective bargaining have sought is not so much a means of convicting workers or unions of violations as a machinery that will prevent strikes, or if strikes occur, bring about their speedy termination. Experience under the older agreements indicates that the best method of securing that result is to set up a procedure that: first, prevents the avoidance of a decision if no settlement by agreement can be reached; second, sets a limit to delays, waivable by mutual agreement while the prospect of settlement by agreement remains; and third, removes, as far as possible, the danger that the workers will suffer "irreparable loss" through delay by providing for compensation from the date of protest in the event that the workers win. The presence of this kind of machinery of adjustment makes it easier for a union to keep its members at work even in the face of an apparent violation of the agreement by affirmative action of the employer. It also makes it easier for the officers to get them to return to work, if they quit, and let the procedure take its course. If the new agreements are to mark the beginning of successful collective bargaining relations in hitherto unorganized industries, it is likely that their procedure for the adjustment of disputes will develop in this direction. 